\title{
Inclusion of Safety Discipline into Pneumatic and Hydraulics Lab Activities
}

\section{Dr. Shoji Nakayama, Purdue University Northwest (College of Technology)}

Dr. Shoji Nakayama is an Associate Professor of Organizational Leadership and Supervision in the Department of Construction Science and Organizational Leadership at Purdue University Northwest. In this position, he teaches safety and health related courses, as well as improving Environmental Health and Safety curriculum through Industrial Advisory Committees. Dr. Nakayama has safety related experience in automotive, airline, regulatory agency and printing industries. He worked as an Environmental, Health, and Safety System Analyst in the telecommunication industry. His research interests include human performance development/improvement, safety performance analysis, integration of safety principles into lean manufacturing, and development of effective online training modules. Dr. Nakayama holds a B.S. in Safety Management and M.S. in Industrial Management from University of Central Missouri and a Ph.D. in Technology Management, with specialization in Human Resource Development and Industrial Training from Indiana State University.

\section{Dr. Ali Alavizadeh, Purdue University Northwest}

Dr. Ali Alavizadeh is an Assistant Professor of Industrial Engineering Technology at Purdue University, Calumet (Hammond, IN). Previously, he taught at Indiana University-Purdue University, Fort Wayne (Fort Wayne, Indiana), The George Washington University (Washington, DC), and Morehead State University (Morehead, KY) in the areas of Industrial Engineering Technology, and Engineering Management and Systems Engineering. His industrial experiences include software engineering, systems engineering and analysis, and production optimization for private, governmental, and nongovernmental organizations. His research interests include complex systems modeling and simulation and systems engineering, and their application in healthcare and aerospace. 


\section{Identifying and Addressing the Gap in Covering Safety Related Topics in Hydraulic and Pneumatic Lab Activities}

\section{Introduction}

One of the important missions for academic institutions is to prepare students for an employment in industry upon graduation. To fulfill this mission, it is essential for institutions to align their program contents with those knowledge and skill sets vital to prospective employers. Moreover, the engineering technology discipline within academic institutions typically emphasizes on applied concepts and laboratory activities so students learn about how to apply the lessons learned in lectures upon graduation. Yet, this is where safety is often overlooked because the main purpose of these lab activities are to focus on the hands-on aspects.

The university is located in the northwest part of the state in a highly urban and industrial area. The campus serves about 9,300 students and it is primarily a commuter campus. The student population consists of about half traditional students and the other half are non-traditional returning students. Engineering Technology (ET) is part of the College of Technology that offers three undergraduate majors: Mechanical Engineering Technology (MET), Mechatronics (MCET), and Electrical and Computer Engineering Technology (ECET). The Organizational Leadership and Supervision (OLS) Program is also, part of the College with a specialization in Environmental Health and Safety (EHS).

Fluid Power is one of the key courses in MET curriculum at the university that is a sophomorelevel course. About $60 \%$ of the course is lecture, which emphasizes on theoretical aspects, and about $40 \%$ of the course is lab activities. Table 1 includes a summary of topics and the corresponding lab activities.

Table 1. The topics and lab activities of fluid power course.

\begin{tabular}{|c|c|c|}
\hline \multicolumn{2}{|c|}{ Lecture } & $\mathrm{Lab}$ \\
\hline \multirow{6}{*}{ Hydraulics } & Principles & No lab \\
\hline & Pumps & \multirow{3}{*}{$\begin{array}{l}\text { Labs } 1,2,3, \text { and } 4 \\
\text { Labs } 6,7,9 \text {, and } 10\end{array}$} \\
\hline & Cylinders & \\
\hline & Values & \\
\hline & Motors & Labs 5 and 8 \\
\hline & $\begin{array}{l}\text { Circuit Design and } \\
\text { Analysis }\end{array}$ & No lab \\
\hline \multirow{3}{*}{ Pneumatics } & Principles & No lab \\
\hline & Cylinders and Valves & Labs 1,2 , and 3 \\
\hline & $\begin{array}{l}\text { Circuit Design and } \\
\text { Analysis }\end{array}$ & No lab \\
\hline
\end{tabular}

As far as the lab section of fluid power course in ET program, some of safety considerations have already been included in hydraulic carts (Refer to as hydraulic trainers here after), as shown 
in Figure 1. However, the pneumatic carts (Refer to as pneumatic trainers here after) lack these features where one needs to further emphasize on safety in a formal manner.

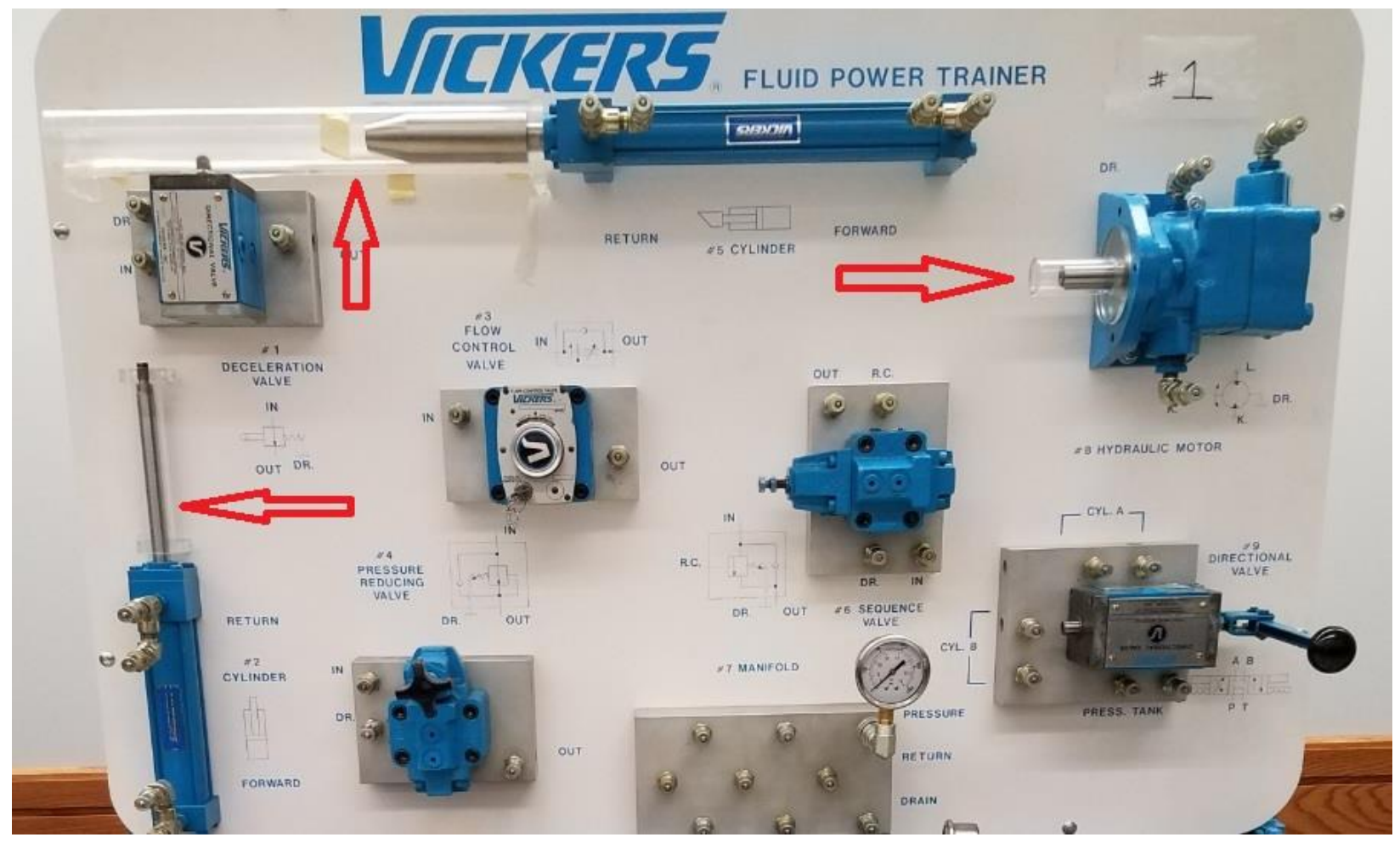

Figure 1. The red arrows show a plastic cover on the cylinders and the motor.

In this paper, the authors report the result of their investigation on identifying a gap between the current safety related issues that are being taught in a fluid power course and what should be taught. This gap can then be fulfilled by creating new components to enhance MET laboratory experience. The core item in this paper will be to use of survey to identity this gap and process taken to reduce the margin of this gap. This process can be applied to ET related disciplines as well as other disciplines in the higher education, where program improvements are needed.

\section{Goals and Scope}

The present project has two phases. The first phase is a preliminary phase in which an initial study was conducted to identify any gap between students' current knowledge of safety related topics surrounding hydraulics and pneumatics system and what they are expected to know in industry. The second phase is to develop industrial-recommended procedures to be covered in lab sessions and to evaluate students' learning through administering a pre-test and a post-test.

The goals of the first phase is, therefore, twofold: (1) to determine whether students have previous academic and/or professional knowledge of hazards/protocols that are being applicable to hydraulics and pneumatics operations, and (2) to discuss the safety elements that should be covered in hydraulic and pneumatic lab activities. The present paper focuses on the first phase of the project. 


\section{Motivation}

Safety issues are critical components for corporate sustainability. According to the Bureau of Labor Statistics (2016), there were a total of 4,836 fatal work injuries recorded in the United States in 2015, which indicated the highest annual figure since 2008.

Hydraulics and pneumatics are two key components of many industrial applications such as transportation and packaging systems. The undergraduate curriculum of Mechanical Engineering Technology (MET) at various universities typically includes a course on fluid power which has a lecture and a lab component. The focus of the lab activities are often on the application of principles covered in the lecture and observing how hydraulic and pneumatic systems work in a hands-on laboratory. However, the extent to which safety such as risk assessment is being discussed in such courses, either in lecture or lab within the engineering technology discipline, is unknown.

The procedure taken in this project will provide guidelines to other institutions to include teaching safety in their lab activities. Such implementations are in conformance with the ABET's General Criteria 4 under ETAC's Continuous Improvement for 2017-2018, which requires each program to regularly assessing and evaluating student outcomes systematically.

The findings from this study will be integrated into a state-of-the-art fluid power laboratory that is currently in the developing stage with an industrial partner. Furthermore, this laboratory will be utilized by both the industry for training and development purposes and by the MET students. The authors will share the results of the study and the process of development and implementation of risk assessment in hydraulics and pneumatics lab activities.

\section{Methodology}

To achieve aforementioned goals, a faculty member from Organizational Leadership and Supervision (OLS) and a faculty member from in Mechanical Engineering Technology (MET), who was also the instructor of the fluid power course, developed a survey (Appendixes A and B) and the students in the course took this survey in fall of 2016 and spring of 2017. The purpose of the survey was to learn about how much the students were being exposed to safety concerns prior to taking the course. Copies of the survey were given to the students during a class session (fall 2016) and prior to first lab session (spring 2017).

\section{Findings}

As stated earlier, the project has the following goals: (1) to determine whether students have previous academic and/or professional knowledge of safety issues/protocols that are applicable to hydraulics and pneumatics system, and (2) to discuss the safety precautions that should be covered in hydraulic and pneumatic lab activities. 
As far as the first goal, the majority of students had limited or no exposure with regards to safety in either hydraulic and/or pneumatic systems. Table 2 summarizes students' responses to the questions relevant to the first goal.

Table 2. A summary of the responses to the first two questions (hydraulic and pneumatic).

\begin{tabular}{|c|c|c|}
\hline \multirow{2}{*}{ Question } & \multicolumn{2}{|c|}{ Semester } \\
\hline & Fall 2016 & Spring 2017 \\
\hline $\begin{array}{l}\text { 1) Have you ever worked with hydraulic systems within a as a } \\
\text { profession professional career? }\end{array}$ & $\begin{array}{ll}- & \text { Yes }(2) \\
- & \text { No }(21)\end{array}$ & $\begin{array}{lc}- & \text { Yes }(5) \\
- & \text { No }(17)\end{array}$ \\
\hline $\begin{array}{l}\text { 2) Have you received any training on safety of hydraulic } \\
\text { systems? }\end{array}$ & $\begin{array}{ll}- & \text { Yes }(2) \\
-\quad & \text { No }(21)\end{array}$ & $\begin{array}{l}-\quad \text { Yes }(3) \\
-\quad \text { No }(19)\end{array}$ \\
\hline $\begin{array}{l}\text { 1) Have you ever worked with pneumatic systems within a as } \\
\text { a profession professional career? }\end{array}$ & $\begin{array}{ll}- & \text { Yes }(3) \\
-\quad & \text { No }(19)\end{array}$ & $\begin{array}{ll}- & \text { Yes }(7) \\
-\quad & \text { No }(15)\end{array}$ \\
\hline $\begin{array}{l}\text { 2) Have you received any training on safety of pneumatics } \\
\text { systems? }\end{array}$ & $\begin{array}{lr}- & \text { Yes }(2) \\
- & \text { No }(19)\end{array}$ & $\begin{array}{ll}- & \text { Yes }(4) \\
- & \text { No }(18)\end{array}$ \\
\hline
\end{tabular}

As far as the second goal, students' responses indicated their inadequate level of knowledge on specific hazards identification, proper methods of control, and appropriate control measures to both human and environment.

\section{Discussion on Hydraulic Safety Competency}

After conducting a literature review, the authors identified the following hydraulic fluid hazards that should be discussed in hydraulics courses (Agency for Toxic Substances and Disease Registry, 1997):

- Can cause skin and eye irritation

- Can cause medical problems. If ingested; seek medical attention immediately.

- May cause medical problems, if repeatedly inhaled (Non-toxic)

- May be corrosive

- No environmental harm.

- Must be disposed of according to environmental regulations.

- High flash point or in certain cases not inflammable at all

- Chemically neutral (not aggressive at all against all materials it touches)

- Low air dissolving capability, not inclined to foam formation

However, students' responses, as shown in Table 3 indicated that there seem to be a gap between what they know and what they should be aware of when it comes to hazards related to hydraulic fluid. 
Table 3. Expert's recommendation vs. Students responses to hazards associated with hydraulic fluid.

\begin{tabular}{|c|c|c|c|}
\hline Experts Recommendations & Semester & Students Reponses & $\begin{array}{c}\text { Number of } \\
\text { Responses / Total } \\
\text { Participants } \\
\end{array}$ \\
\hline \multirow[t]{2}{*}{$\begin{array}{l}\text { 1. Can cause skin and eye } \\
\text { irritation }\end{array}$} & Fall 2016 & $\begin{array}{l}\text { Fluid with skin Eye } \\
\text { injury }\end{array}$ & $12 / 23$ \\
\hline & Spring 2017 & Skin and eye irritation & $10 / 22$ \\
\hline \multirow{2}{*}{$\begin{array}{l}\text { 2. Can cause medical } \\
\text { problems. If ingested; } \\
\text { seek medical attention } \\
\text { immediately. }\end{array}$} & Fall 2016 & $\begin{array}{l}\text { Fluids from hydraulic } \\
\text { system }\end{array}$ & $2 / 23$ \\
\hline & Spring 2017 & Fluid may be harmful. & $2 / 22$ \\
\hline \multirow{2}{*}{$\begin{array}{l}\text { 3. May cause medical } \\
\text { problems, if repeatedly } \\
\text { inhaled (Non-toxic) }\end{array}$} & Fall 2016 & None & $0 / 23$ \\
\hline & Spring 2017 & None & $0 / 22$ \\
\hline \multirow[t]{2}{*}{ 4. May be corrosive } & Fall 2016 & Chemical hazards (burns) & $1 / 23$ \\
\hline & Spring 2017 & Avoid contact & $1 / 22$ \\
\hline \multirow{2}{*}{ 5. Environmental harm. } & Fall 2016 & Oils spill (Leakage) & $9 / 23$ \\
\hline & Spring 2017 & Leak, Oil spill & $2 / 22$ \\
\hline \multirow{2}{*}{$\begin{array}{l}\text { 6. Must be disposed of } \\
\text { according to } \\
\text { environmental } \\
\text { regulations. }\end{array}$} & Fall 2016 & None & $0 / 23$ \\
\hline & Spring 2017 & None & $0 / 22$ \\
\hline \multirow{2}{*}{$\begin{array}{l}\text { 7. High flash point or in } \\
\text { certain cases not } \\
\text { inflammable at all }\end{array}$} & Fall 2016 & None & $0 / 23$ \\
\hline & Spring 2017 & Flammable & $3 / 22$ \\
\hline \multirow{2}{*}{$\begin{array}{l}\text { 8. Chemically neutral (not } \\
\text { aggressive at all against } \\
\text { all materials it touches) }\end{array}$} & Fall 2016 & None & $0 / 23$ \\
\hline & Spring 2017 & None & $0 / 22$ \\
\hline \multirow{2}{*}{$\begin{array}{l}\text { 9. Low air dissolving } \\
\text { capability, not inclined } \\
\text { to foam formation }\end{array}$} & Fall 2016 & None & $0 / 23$ \\
\hline & Spring 2017 & None & $0 / 22$ \\
\hline
\end{tabular}

Furthermore, Table 3 highlights those areas where students lack information on how to keep themselves and others safe while working on hydraulic systems. More specifically, students were not aware of the recommended practices numbered 3, 6, 7, 8, and 9 in the table. Plus, there seems to be a lack of knowledge with regard to procedures (steps) to depressurize pneumatics systems.

\section{Discussion on Pneumatic Safety Competency}

As far as pneumatic systems, experts indicate the following proper steps associated with pneumatic systems (ComAir, 2007) 
Step 1: Isolate compressor from system.

Step 2: Depressurize compressor and pipe work.

Step 3: Check that compressor pressure gauge reads zero.

While these steps are necessary for the students to know, their responses once again indicated a significant gap between what they know and what they should be aware of, as shown in Table 4 .

Table 4. Expert's recommendation vs. students' responses to a typical procedure (steps) to depressurize pneumatics systems.

\begin{tabular}{|c|c|c|c|}
\hline $\begin{array}{c}\text { Experts } \\
\text { Recommendations }\end{array}$ & Semester & Students Reponses & $\begin{array}{c}\text { Number of } \\
\text { Responses / Total } \\
\text { Participants }\end{array}$ \\
\hline \multirow[t]{2}{*}{$\begin{array}{l}\text { 1.Isolate Compressor } \\
\text { From System }\end{array}$} & Fall 2016 & $\begin{array}{l}\text { Pressing the button after the } \\
\text { FRL and then shutting off the } \\
\text { valve, Turn off air supply }\end{array}$ & $6 / 23$ \\
\hline & $\begin{array}{l}\text { Spring } \\
2017\end{array}$ & $\begin{array}{l}\text { Turn off machine, Lockout } \\
\text { Tagout, Close the pressure } \\
\text { valve, Shut the main air lines }\end{array}$ & $10 / 22$ \\
\hline \multirow[t]{2}{*}{$\begin{array}{l}\text { 2.Depressurize } \\
\text { Compressor and Pipe } \\
\text { Work }\end{array}$} & Fall 2016 & $\begin{array}{l}\text { Release the air (Bleed system } \\
\text { of air), Disconnect from } \\
\text { furthest point (release pressure } \\
\text { to greatest pressure source) }\end{array}$ & $6 / 23$ \\
\hline & $\begin{array}{l}\text { Spring } \\
2017\end{array}$ & $\begin{array}{l}\text { Release/Bleed emergency } \\
\text { valve }\end{array}$ & $8 / 22$ \\
\hline \multirow[b]{2}{*}{$\begin{array}{l}3 \text { Check that compressor } \\
\text { pressure gauge reads } \\
\text { zero } \\
\text { (Air Exhausting to } \\
\text { Atmosphere can be } \\
\text { Dangerous....) }\end{array}$} & Fall 2016 & None & $0 / 23$ \\
\hline & $\begin{array}{l}\text { Spring } \\
2017\end{array}$ & None & $0 / 22$ \\
\hline \multirow{2}{*}{$\begin{array}{l}\text { 4.Direct Discharge Air } \\
\text { Away from the Unit \& } \\
\text { Operator }\end{array}$} & Fall 2016 & None & $0 / 23$ \\
\hline & $\begin{array}{l}\text { Spring } \\
2017\end{array}$ & None & $0 / 22$ \\
\hline \multirow[b]{2}{*}{$\begin{array}{l}\text { 5.Clear Area of any } \\
\text { Flying Hazards Before } \\
\text { Discharge } \\
\text { (Use Hearing } \\
\text { Protection During Any } \\
\text { Depressurization) }\end{array}$} & Fall 2016 & None & $0 / 23$ \\
\hline & $\begin{array}{l}\text { Spring } \\
2017\end{array}$ & None & $0 / 22$ \\
\hline
\end{tabular}

As Table 4 indicates, the majority of students who use pneumatic systems were not aware of those critical steps (mentioned above) or knowledge that are essential to keep themselves and others safe. Items indicated as 3, 4 and 5 were not even mentioned by students. 


\section{Conclusion and Recommendation}

The result indicates that the surveyed students were not properly prepared in the area of safety precautions surrounding hydraulic and pneumatic systems. As it is the academic institution's mission to help prepare students for their future endeavors, it is imperative to align lab activities with those concepts/skill sets that are practiced in industry. Therefore, pneumatic/hydraulics instructors are recommended to develop and provide lecture materials covering the following areas:

For hydraulic laboratory (Table 3):

a) For item 3, 7, 8, and 9: Include exercises and information that allow students to be able to identify certain hazards of fluids being used and recognize how to protect themselves and others based on its Safety Data Sheet (SDS).

b) For the item 6: Include course materials that covers appropriate disposal of and recognition of flammable properties of hydraulic fluids. Such materials or instructional materials also need to inform students about hazards surrounding hydraulic systems including awareness of proper procedure before working on the system such as bleeding.

For pneumatic laboratory (Table 4):

a) For the item 3, 4, and 5: Include a proper operating procedure before use of any pneumatic components. Furthermore, students should be aware of appropriate procedures to depressurize pneumatics systems, and other hazards surrounding utilization of pneumatic systems.

By incorporating above instructional materials, whether it is a topic to be covered during lecture or exercises to be included into laboratory experiences, it allows students to be able to recognize relevant hazards surrounding hydraulic and pneumatic operations. This allows students to be able to practice how to identify, prevent, and/or mitigate those hazards. This practice provides graduates with necessary tools to not only protect themselves and others, but also their company's assets.

For the second phase of this project, the authors will proceed to develop experiential learning components based on industrial-recommended procedures identified in the first phase. Upon teaching the experiential learning components, the authors will assess students' learning through administering a pre-test and post-test. 


\section{Appendix A}

Questionnaire Used to Conduct the Phase 1 of the Study

\section{Pneumatic Safety Questions}

Best of your knowledge, please answer the following questions.

QUESTION 1) Have you ever worked with pneumatic systems within a as a profession professional career?

Yes__ No

IF yes, how long and on which system:

3 years $\quad 1 \sim 3$ years $<1$ year None

QUESTION 2) Have you received any training on safety of pneumatics systems?

Yes__ No___

If yes, what was the format? (workshop, online training, etc.)

QUESTION 3) What are some of the hazards associated with a compressors?

QUESTION 4) What precautionary measures must be taken before working on a compressor and/or pipe work?

QUESTION 5) What is a typical procedure (steps) to depressurizing pneumatics systems?

QUESTION 6) Does an operator need to have any Personal Protective Equipment (PPE) when working on pneumatics systems? If yes, what are they? If no, why not?

QUESTION 7) What other hazards exist concerning pneumatics systems?

QUESTION 8) What is the typical process (or steps) to take before working on pneumatics systems that is supplied by electrical system? 


\section{Appendix B}

Questionnaire Used to Conduct the Phase 1 of the Study

\section{Hydraulics Safety Questions}

Be able to identify the fundamental parts of a hydraulic system and safety issues relating to hydraulics

You will explore some of the safety issues associated with hydraulic systems and the fluids used in them.

QUESTION 1) Have you ever worked with hydraulic systems within a as a profession professional career?

Yes No

IF yes, how long and on which system:

3 years $\quad 1 \sim 3$ years $\quad<1$ year None

QUESTION 2) Have you received any training on safety of hydraulic systems?

Yes No

If yes, what was the format? (workshop, online training, etc.)

QUESTION 3) List hazard(s) associated with the use of hydraulic systems.

QUESTION 4) What are the general safety procedures for working on hydraulic systems?

QUESTION 5) What are the hazards associated with hydraulic fluid?

QUESTION 6) How would you control/mitigate those hazards that you listed in Question 5? 


\section{Bibliography}

1. ABET. (2017). Criteria for accrediting applied science program. Retrieved March 6, 2017 from http://www.abet.org/accreditation/accreditation-criteria/criteria-for-accreditingengineering-technology-programs-2017-2018/\#continuous

2. Agency for Toxic Substances and Disease Registry. (1997). Hydraulic Fluids. Retrieved February 1, 2017 from https://www.atsdr.cdc.gov/phs/phs.asp?id=755\&tid=141

3. Bureau of Labor Statistics (BLS). (2016). Census of Fatal Occupational Injuries Summary, 2015. Retrieved March 6, 2017 from https://www.bls.gov/news.release/cfoi.nr0.htm

4. ComAir. (2007, October). Compressed Air Safety Global Service Training Compressed Air Safety Training Module Tristan Blanchard October 2007 Issue 2. Retrieved January 30, 2017, from http://slideplayer.com/slide/4762816/ 